doi: 10.18484/2305-0047.2021.4.426

O.M. KLIMOVA ${ }^{1}$, V.V. BOYKO ${ }^{1}$, L.A. DROZDOVA ${ }^{1}$, O.V. LAVINSKA D.V. MINUKHIN ${ }^{2}$, A.N. KUDREVICH ${ }^{3}$

\title{
PROGNOSTIC MARKERS IN PATIENTS WITH THYMUS-INDEPENDENT AND THYMUS-DEPENDENT MYASTHENIA GRAVIS
}

\author{
V.T. Zaycev Institute of General and Urgent Surgery of National Academy of Medical Sciences of Ukraine ${ }^{1}$, \\ Kharkiv National Medical University ${ }^{2}$, \\ V. N. Karazin Kharkov National University ${ }^{3}$, Kharkov, \\ Ukraine
}

Цель. Оценить наличие специфических маркеров у пациентов с тимуснезависимой и тимусзависимой миастенией для выбора тактики лечения.

Материал и методы. Обследовано 138 пациентов с тимуснезависимой (М - миастения без морфофункциональных изменений тимуса) и тимусзависимой (МГ - миастения на фоне гиперплазии тимуса, МТ - миастения на фоне тимомы) миастенией. Использовали методы иммуноферментного анализа (содержание антител к $\alpha 1$ и $\alpha 7$ субъединицам нАХР в сыворотке, к $\alpha 7$ субъединице нАХР в митохондриях тимоцитов, уровень антиядерных антител ANA), иммунофлуоресценции (тип свечения ANA), проточной цитометрии (экспрессия CD14+CD11c+ и CD14+HLA-DR+).

Результаты. Выявлена взаимосвязь клинических фенотипов миастении с вариантами диплотипов лейкоцитарных антигенов HLA: у молодых пациентов с тимуснезависимой миастенией (M) выявили высокую гетерогенность генотипических маркеров HLA-DR (DR1, DR2, DR3, DR5, DR7). Пациенты с тимусзависимой миастенией (MT) имели только дипло- и гаплотипы HLA DR2 и HLA DR7. Наличие гаплотипов HLA DR2 и HLA DR7 у части молодых пациентов с М при прогрессировании заболевания приводило к развитию миастении на фоне тимомы (MT) в старшем возрасте. Патогенетическая роль также принадлежит инфекции (CMV, EBV, HBV, HCV, HSV-1, HSV-2, HHV-6, микоплазма) и пищевой непереносимости (IgE и $\mathrm{IgG} 4)$ в развитии и прогрессировании миастении. В качестве дополнительной мишени аутоагрессии при миастении выявили четырехкратное преобладание $\alpha 7$ субъединицы никотиновых ацетилхолиновых рецепторов в митохондриях клеток тимомы. Специфические антинуклеарные антитела к центромерам хромосом были визуализированы у пациентов старшей группы с миастенией на фоне тимомы.

Заключение. Прогноз прогрессирования миастении и развития ремиссии может быть осуществлен с помощью геномных (наличие определенных гаплотипов HLA-DR) и молекулярных (антитела ANA к центромерным белкам хромосом, экспрессия CD20+, CD14+CD11c+, CD14+HLA-DR+) биомаркеров, которые могут быть применены для выбора тактики лечения.

Ключевые слова: миастения, гиперплазия тимуса, тимома, антиядерные антитела, кластер дифференцировки

Objective. To assess the presence of specific markers in patients with thymus-independent and thymusdependent myasthenia gravis for choosing treatment tactics.

Methods. The presence of specific markers was assessed in 138 patients with thymus-independent (M myasthenia gravis without thymus changes) and thymus-dependent (MH - myasthenia gravis with thymus hyperplasia, MT - myasthenia gravis with thymoma). The method ELISA (the content of antibodies to subunits 1 and $7 \mathrm{nAChR}$ in blood serum, to $7 \mathrm{nAChR}$ subunit in thymocyte mitochondria, a detectable level of antinuclear antibody (ANA), immunofluorescence (ANA glow) and flow cytometry (expression of CD14+CD11c+and CD14 + HLA-DR +) has been used.

Results. The relationship between the clinical phenotypes of myasthenia gravis and the variants of HLA diplotypes was revealed: in young patients with thymus-independent myasthenia gravis (M), a high heterogeneity of the genotypic markers HLA-DR (DR1, DR2, DR3, DR5, DR7) was detected. Patients with thymus-dependent myasthenia (MT) had only the HLA DR2 and HLA DR7 diplo- and haplotypes. The presence of HLA DR2 and HLA DR7 haplotypes in some young patients with progressive thymus-independent myasthenia gravis (M) led to the development of myasthenia gravis with thymoma (MT) in the elderly people. The pathogenic role also belongs to infection (CMV, EBV, HBV, HCV, HSV-1, HSV-2, HHV-6, mycoplasma) and food intolerance (IgE and IgG4) in the development and progression of myasthenia gravis. A four-fold prevalence of $\alpha 7$ subunit nicotinic acetylcholine receptors on the thymocyte mitochondria as an additional targets of autoimmune aggression in myasthenia gravis was determined. Specific antinuclear antibodies to centromere chromosome proteins were visualized in the elderly people with thymoma.

Conclusion. The prognosis of the myasthenia gravis progression and the development of remission can be made using genomic (the presence of certain HLA-DR haplotypes) and molecular (ANA antibodies to centromere chromosome proteins, expression of $\mathrm{CD} 20+, \mathrm{CD} 14+\mathrm{CD} 11 \mathrm{c}+, \mathrm{CD} 14+\mathrm{HLA}-\mathrm{DR}+)$ biomarkers, that can be used for the choice of treatment tactics.

Keywords: myasthenia gravis, thymus hyperplasia, thymoma, antinuclear antibodies, differentiation cluster 
Novosti Khirurgii. 2021 Aug-Sep; Vol 29 (4): 426-433

Prognostic Markers in Patients with Thymus-Independent

and Thymus-Dependent Myasthenia Gravis

O.M. Klimova, V.V. Boyko, L.A. Drozdova, O.V. Lavinska, D.V. Minukhin, A.N. Kudrevich

\section{Научная новизна статьи}

Впервые изучено изменение комплекса определенных биомаркеров для прогноза и выбора тактики комплексного лечения для молодых пациентов с тимуснезависимой миастенией и для пациентов старшего возраста с тимусзависимой миастенией при прогрессировании заболевания. При наличии определенных гаплотипов HLA-DR, антинуклеарных антител к центромерным белкам хромосом, увеличении экспрессии CD20+, CD14+CD11c+ и CD14+HLA-DR+ аналогичных биомаркерам при тимусзависимой миастении на фоне тимомы, у части молодых пациентов с тимуснезависимой миастенией выполнение тимэктомии может иметь высокую эффективность.

\section{What this paper adds}

The change of complex biomarkers has been firstly studied for prognosis and choice of complex treatment tactics for young patients with progressive thymus-independent myasthenia gravis and for the elderly patients with thymusdependent myasthenia gravis. In the presence of certain HLA-DR haplotypes, antinuclear antibodies to centromere chromosome proteins, an increasing expression of CD20+, CD14+CD11c+ and CD14+HLADR+ in some young patients with thymus-independent myasthenia gravis, analogically to biomarkers in thymus-dependent myasthenia gravis with thymoma, to perform a thymectomy is of high dangerous. potential risks of the procedure.

\section{Introduction}

Myasthenia gravis (MG) incidence has increased worldwide in 20 folds over the past 15 years [1]. Myasthenia gravis manifests as a generalized progressive muscle weakness due to defective synaptic transmission between the nerve terminal and the muscle. Structural and functional disorders in the thymus as the central organ of immunity are revealed in some patients with myasthenia. The heterogeneity of the clinical forms of myasthenia gravis depends on the many pathogenetic mechanisms that underlie this multifactorial autoimmune disease [2]. The onset of the disease in young patients with thymusindependent myasthenia $(\mathrm{M})$ is characterized by a low degree of severity. Disease progression can lead to various types of thymus-dependent myasthenia gravis (associated with thymus hyperplasia $(\mathrm{MH})$ and thymoma (MT)) in the elderly people for whom surgery is not effective and is often accompanied by morbidity and mortality [3].

Current approaches to the treatment of myasthenia gravis are determined by standard treatment and include anticholinesterase drugs, corticosteroids, plasmapheresis and surgical treatment. Removal the thymus which has been shown to play a role in the development of myasthenia gravis as the target of autoimmune aggression does not mean the exclusion of the anticholinesterase drugs use, and sometimes leads to the development of myasthenic and cholinergic crises [4].

The treatment of myasthenia gravis is not always effective ( $45 \%$ of patients), and it appears to be important to search for innovative approaches to diagnosis and a personalized approach to treatment by identifying the integral and differential markers characterizing the central and peripheral mechanisms of self-tolerance loss.

\section{Objective}

To estimate the presence of specific markers in patients with thymus-independent and thymusdependent myasthenia gravis for further choice of treatment tactics.

\section{Methods}

The patients ( $n=138$, age 13-70 years) with different clinical phenotypes of myasthenia gravis: $\mathrm{M}-$ thymus-independent myasthenia gravis $(n=47$, 15 men and 32 women), MT - thymus-dependent myasthenia gravis with thymoma $(\mathrm{n}=52,32$ men and 20 women), $\mathrm{MH}$ - thymus-dependent myasthenia gravis with hyperplasia $(\mathrm{n}=39,11 \mathrm{men}$ and 28 women) have been examined. Integral and differential research methods were used in the study. The diagnosis was made on the basis of determining muscle weakness and pathological muscle fatigue, decrement pattern of M-response with rhythmic stimulation, and taking into account the temporal reversibility of clinical and electromyographic changes during the proserin test. Determining the cause of muscle weakness involves distinguishing primary weakness from fatigue or asthenia.

The association of the presence of leukocyte antigens haplo- and diplotypes of the second class HLA-DR with various clinical phenotypes of myasthenia gravis was evaluated using a microlymphocytotoxic test (Terasaki test) [5].

The determination of antibodies to $\alpha 1$ and a7 subunits of nicotinic acetylcholine receptors (nAChR) was performed by enzyme-linked immunosorbent assay (ELISA) using the recombinant extracellular domains 1 (1-208) and 7 (1-208) as antigens. The results obtained were presented in units of optical density at a wavelength of 490 $\mathrm{nm}[6]$. 
For the determination of an additional autoimmune target of $\alpha 7$ subunits nicotinic acetylcholine receptors (nAChRs) in mitochondria of thymus/ thymoma preparations a cell suspension was obtained by homogenizing of organ in Hanks solution and further filtering through a nylon filter.

The preparation of isolated mitochondria from the thymus and thymoma was derived by differential centrifugation at $1000 \mathrm{~g}$ and $10000 \mathrm{~g}$. To receive a mitochondrial precipitate the isolation medium of the following composition was used: $10 \mathrm{mM}$ HEPES, $200 \mathrm{mM}$ sucrose, $1 \mathrm{mM}$ EDTA-1 (pH 7.4). Isolation of mitochondria was carried out at $2^{\circ} \mathrm{C}$. Mitochondria were suspended in an incubation medium of the following composition: $10 \mathrm{mM}$ HEPES, $125 \mathrm{mMKCl}, 25 \mathrm{mMNaCl}, 0.1 \mathrm{mM} \mathrm{P}$ (as K-phosphate buffer, $\mathrm{pH} 7.4$ ), $5 \mathrm{mM}$ sodium succinate $\left(22{ }^{\circ} \mathrm{C}\right)$. The protein concentration in mitochondria was determined by the Bradford method $(0.20 \mathrm{mg} / \mathrm{ml})$. The level of $\alpha 7$ subunits of mitochondrial nAChR in thymus preparations was determined by ELISA [6].

The expression value of common leukocyte antigen CD20 was determined by indirect immunofluorescence method using monoclonal antibodies (Sorbent, Russia) labeled with FITCstain. Immunofluorescent labeling of centromeres were visualized by fluorescent microscope Olympus BX53 (with magnification x1000).

The cells stained by corresponding antibodies were visualized by fluorescent microscope Olympus BX53 (with magnification x1000).

The expression of monocyte activation markers was evaluated by flow cytometry using monoclonal antibodies CD14-FITC, CD11c-PE, Anti-HLADR-PE (Beckman Coulter, USA). The analysis was performed 2 hours after blood sampling using test tube with the K3 EDTA according to the standard protocol.

In each sample, at least 10000 cells were analyzed. For correct exclusion cells that did not meet the parameters from the analysis zone, the necessary logical constraints were introduced into the particle distribution histogram for low-angle, lateral scintillation (SSC).

The evaluation of expression of receptors on the cell surface by mean fluorescence intensity was performed. To remove erythrocytes the sample preparation was carried out with no-wash technology using OptiLyse C (Beckman Coulter, USA). The analysis of stained cells was carried out on a flow cytometry Cytomics FC500 (Beckmann Coulter, USA) [7].

To identify serum specific antibodies to nuclear structures (ANA) in all patients with thymusindependent (M) and thymus-dependent myasthenia (MH and MT), a multispecific screening test was performed by indirect quantitative ELISA testing.

The diluted serum samples were incubated in the wells of a tablet coated with a mixture of purified antigens SS-A (52 kDa), SS-A (60 kDa), SS-B, RNP-70, Sm, RNP / Sm, Scl-70, Centromere B. Patient's serum samples linked with specific antigens were identified by means of conjugation of enzymes to antibodies (against human IgG).

A substrate-chromogenic reagent was added to the wells, which was converted into a stained product under the influence of the peroxidase conjugate.

To calculate the concentration of ANA in blood serum, the standard formula containing a known amount of ANA (Reagent Kit ANA screen, Orgentec, Germany) was applied.

With a positive result of such a screening examination, an additional visual determination of the type of ANA and the nature of their binding to various peptide fragments of cell nuclei was performed using the indirect immunofluorescence method.

The results were evaluated using a fluorescent microscope, taking into account the type of glow (Euroimmun reagent kit, Germany).

\section{Statistics}

Statistical processing of data was carried out taking into account the normal distribution. The mean $(\mathrm{m})$ and standard deviation (SD) of the mean value were determined. Student's test (t-test) was used. The differences in mean values were considered to be reliable at $\mathrm{p}<0.05$.

\section{Results}

Initially HLA DR class II leukocyte antigens as genomic markers were studied in patients with various types of myasthenia gravis. It was established that in young patients with thymus-independent myasthenia (M), there was a high heterogeneity of the genotypic markers HLA-DR (DR1, DR2, DR3, DR5) and only $20 \%$ had DR7.

In patients with thymus-dependent myasthenia gravis against the background of thymus hyperplasia, the HLA DR1 and HLA DR5 haplotypes were encountered with a high frequency. Patients with thymus-dependent myasthenia (MT against the background of thymoma) had only the HLA DR2 and HLA DR7 diplo- and haplotypes. The presence of HLA DR2 and HLA DR7 haplotypes in some young patients with progressive thymus-independent myasthenia gravis (M) led to the development of myasthenia gravis on the background of thymoma (MT) in elderly people.

Autoantibodies to $\alpha 7$ subunit of $\mathrm{nAChR}$ 


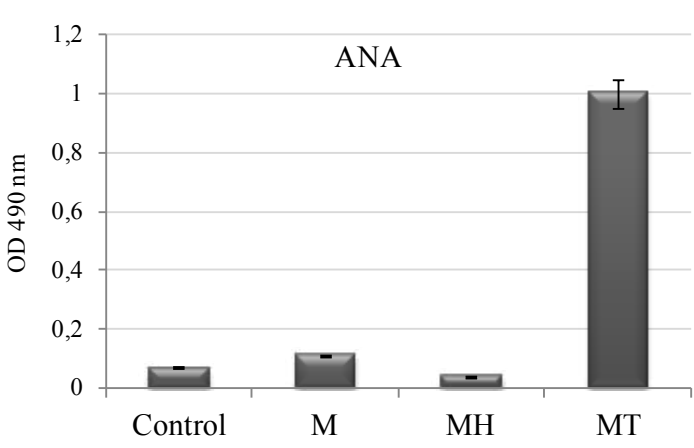

Fig. 1. The concentration of antinuclear antibodies ANA in patients with thymus-independent (M) and thymus-dependent myasthenia gravis (MH, MT).

were found only in $20 \%$ of young patients with thymus-independent myasthenia (M), and in all elderly patients with thymus-dependent myasthenia (MT). Thus, this indicates the similarity of the mechanisms of self-tolerance loss in groups $\mathrm{M}$ and MT [3].

Since the structural and functional changes in the thymus in thymus-dependent myasthenia may be linked with a violation of the formation mechanisms of central self-tolerance in the thymus, the presence of nAChR on the thymocyte mitochondria was determined.

A fourfold prevalence of the $\alpha 7 \mathrm{nAChR}$ subunit presence in the mitochondria of thymus cells was revealed in comparison with the cells of intact thymus. That is, nAChR receptors in thymocyte mitochondria are an additional factor in the formation of the central mechanism of self-tolerance loss in patients with thymus-independent myasthenia (M) and patients with thymus-dependent myasthenia with thymoma (MT).

Antinuclear antibodies (ANA) as differential specific markers were detected only in patients with thymus-dependent myasthenia of the older age group (MT (14 times higher than the control according to the quantitative method ELISA) (Fig. 1).

To determine the target of autoantibodies the additional studies were carried out to visualize specific targets in the cell nucleus. Unique anti-nuclear ANA antibodies to centromere chromosome proteins were detected only in the elderly patients with thymus-dependent myasthenia gravis with thymoma (MT) (Fig. 2, 3).

Fig. 2. Autoantibodies to the centromeres of chromosomes in patient $K$. with thymoma (MT) (A) and to the centromere protein $\mathrm{F}$ (CTNPF) in patient $\mathrm{N}$. with thymoma MT (B). FITC staining of standard HEp-2 antigenic substrates after interaction with serum antibodies.
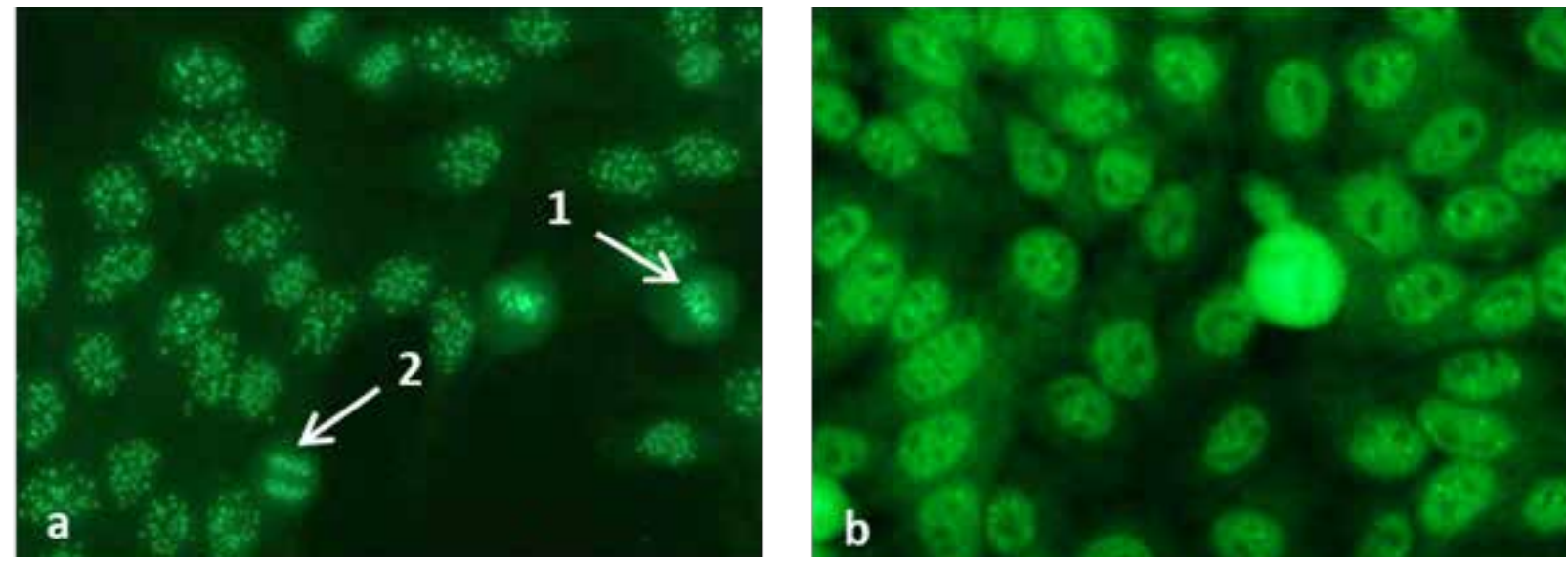

Fig. 3. Expression of CD11c+ (a) and HLA-DR+ (b) on monocytes.
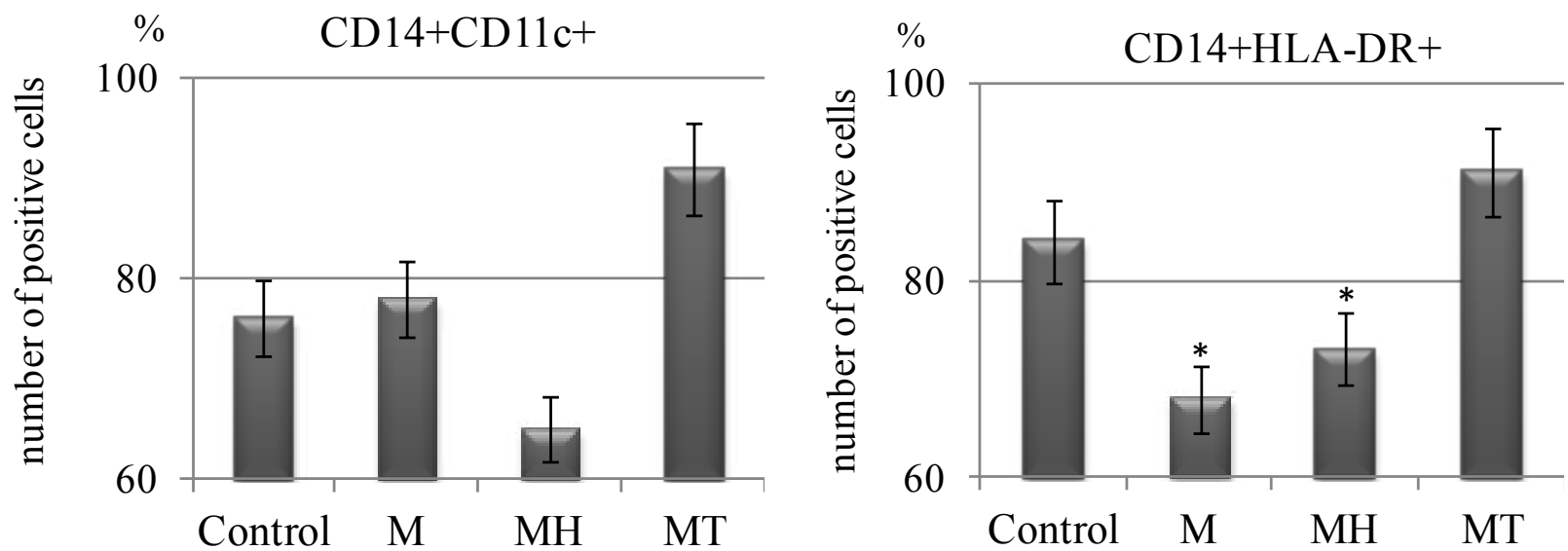
The characteristic type of antibodies luminescence to chromosomal centromeres was revealed: the type of granules was small in size (46 or 92 centromeres per nucleus).

The granules were evenly distributed in the nucleus of the interphase cell, whereas in mitotic cells they formed a ribbon-like structure - one in metaphase (Fig. 2a-1) or two parallel in anaphase (Fig. 2a-2).

Patients with MT had a mottled nuclear pattern of various intensities with the strongest staining in the G2 phase and weak staining in G1 (Fig. 2b), which indicates the presence of autoantibodies for the Centromere protein F. Centromeres were positive only in pro-metaphase and metaphase. The surrounding cytoplasm of mitotic cells is diffusely stained. Antibodies to chromosome centromeres in metaphase were detected only in the MT group. Also, in MT group, ANA was revealed to the achromatin spindle protein NUMA, to the antigen of the mitotic spindle fibers MSA-2, to the cytoskeleton proteins cytokeratin and tropomyosin.

In this study, we evaluated the significant surface antigens expressed on immunocompetent cells in the implementation of the immune response in myasthenia gravis.

Membrane expression of CD20+ antigens makes it possible to evaluate the concentration of mature B-cells - producers of immunoglobulin. Expression of CD20+ was significantly increased to $27.1 \pm 3.2 \%$ at initial values $(11.0 \pm 2.6) \%$ in the group of patients with MT, which indicates the activation of the functional activity of B-lymphocytes. These changes were insignificant in group $\mathrm{M}$ and $\mathrm{MH}-(18.9 \pm 2.8) \%$ and $(13.4 \pm 1.6) \%$, respectively.

Cluster of differentiation of CD11c+ on monocytes, determining chemotaxis and adhesion during inflammation were at the control level in young patients with thymus-independent myasthenia (M). The CD14+CD11c+ concentration increased by $20 \%$ with disease progression in the elderly MT patients (Fig. 3a). The expression of $\mathrm{CD} 11 \mathrm{c}+$ on monocytes was minimal and amounted to $65.0 \pm 3.4 \%$ in patients with thymus hyperplasia $(\mathrm{MH})$.

The intensity of HLA-DR leukocyte antigens expression on monocytes was reduced in young patients with thymus-independent myasthenia (M) at the onset of the disease. The HLA-DR expression in the elderly ones with thymoma (MT) increased by $35 \%$ at the disease progressed (Fig. 3b). Therefore, the antigenic load during the myasthenia gravis progression can lead to an increase in the markers of inflammation CD11c+ and HLA-DR+ on monocytes.

\section{Discussion}

The relationship between the clinical phenotypes of myasthenia gravis and the variants of human leukocyte antigens (HLA), which are genetic factors that form various types of immune reactivity and determine resistance vectors, was revealed in this study. Human leukocyte antigens are marker proteins of receptors that recognize foreign antigens and carry out immunogenetic control by changing the density of receptor expression on the cell surface. The specific associations of leukocyte antigens in different phenotypes of myasthenia gravis $(\mathrm{M}, \mathrm{MH}$ and MT) can be used as prognostic markers for the development of immune imbalance that develops during the latent period of the formation of autoimmune pathology or during remission. The presence of HLA haplotypes DR2 and DR7 in some young patients with progressive myasthenia gravis (M) led to the development of myasthenia gravis with thymoma (MT) in the elderly people.

Infections and food intolerance play a certain pathogenetic role in the self-tolerance loss in thymus-dependent and thymus-independent myasthenia gravis.

The clinical phenotypes of myasthenia gravis associated with the accumulation of antigenic load - bacterial and viral infections (CMV; EBV; HBV, HCV, HSV1, HSV2, HHV6; mycoplasma), induced food intolerance of IgE and IgG4, an increase of the concentration of IFN- $\gamma$ and others cytokines [8].

Autoantibodies to nicotinic acetylcholine receptors (nAChR) of the neuromuscular synapse are found to be the main pathogenetic factors of the self-tolerance loss in patients with myasthenia gravis.

The maximum increase of the concentration of antibodies to the $\alpha 1$ and $\alpha 7$ subunits of nAChR was revealed in patients with $\mathrm{M}$ and $\mathrm{MH}$. In patients with thymoma the concentration of specific antibodies to different domains of nAChR did not significantly differ from the control values. Therefore, in patients with MT, the pathogenetic factor of the development of myasthenic syndrome and crisis may have other mechanisms not associated with the presence of antibodies to nAChR.

According to Hurst et al. (2013) the function of mitochondrial nAChR should control the formation of a mitochondrial transittion pore, which is a source of proapoptotic factors and reactive oxygen species (ROS) released in the cytosol [9].

In additional, the level of $\alpha 7$ subunits of nAChR is higher in the thymus of patients with thymoma, therefore, tumor transformation is accompanied by an increasing mitochondrial nAChR, which supports the viability of tumor cells.

The synthesis of autoantibodies indicates the main role of $\mathrm{B}$ cells in the pathogenesis of 
myasthenia gravis [10]. Dysregulation of immune cells indicates that a combination of various factors (increased expression of CD20+, antinuclear antibodies (ANA) contributes to the manifestation of the disease.

The body's immune responses to various antigens are determined by the processes of proliferation, programmed death and differentiation by the involvement of immunocompetent cells. Molecules of the activation, proliferation and apoptosis are expressed on the immunocompetent cells surface during differentiation processes.

Monocytes, depending on their microenvironment, can differentiate into multiple cell types. The inflammation process is characterized by the stage and degree of the LPS-binding protein expression and expression of the HLA-DR receptors that determine the response of antigen-presenting cells to the foreign antigens [11].

In certain inflammatory conditions, monocytes increase the expression of CD11c dendritic cell markers $(\mathrm{CD} 14+\mathrm{CD} 11 \mathrm{c}+)$ along with $\mathrm{MHC}$ (CD14+HLA-DR+) and co-stimulatory molecules $(\mathrm{CD} 4+\mathrm{CD} 28+)$ [3].

The results described in this article demonstrate changes in the synthesis of specific antibodies to cell nucleus certain structures (such as centromeres, the achromatin spindle protein NUMA, antigen of the mitotic spindle fibers MSA-2, cytoskeletal proteins), the level of nAChR in the thymocytes mitochondria, impaired expression of cell receptors in thymus-independent and thymus-dependent myasthenia gravis.

These data are a consequence of the metabolic mechanisms violation of the central and peripheral self-tolerance loss in patients with myasthenia gravis, and, accordingly, should be taken into account in targeted therapy aimed at individual pathogenetic links of the autoimmune process.

\section{Conclusions}

The specific markers characterizing the immune mechanisms of the processes formation of central and peripheral self-tolerance loss in young patients with thymus-independent myasthenia gravis (M) and in the elderly patients with thymus-dependent myasthenia gravis (myasthenia gravis with thymus hyperplasia - MH, myasthenia gravis with thymoma MT) have been revealed in this study.

In patients with $\mathrm{M}$, heterogeneity of HLA-DR genotypic markers (DR1, DR2, DR3, DR5) was revealed, and only $20 \%$ had DR7; the same patients showed a pronounced activation of the differentiation cluster CD20+ expression on B-lymphocytes antibody producers; multiple increase in the expression of adhesion molecules on phagocytic mono- cytes CD14+CD11c+.

In patients with $\mathrm{MH}$, the other patterns was detected: the presence of HLA DR1 and HLA DR5 haplotypes; pronounced inhibition of the expression of adhesive molecules CD14+CD11c+ and a reduction of the marker of monocytes late activation CD14+HLA-DR+.

The development of thymoma in patients has always been associated with both the formation of a central self-tolerance loss (the presence of the HLA DR2 and HLA DR7 haplotypes; the presence of additional targets for autoantibodies $-\alpha 7$-subunits of nicotinic acetylcholine receptors (nAChR) in the thymocytes mitochondria; multiple increase of concentration of antinuclear antibodies (ANA) in patients and a wide spector of their specificity (to the achromatin spindle protein NUMA, to the antigen of the mitotic spindle fibers MSA-2, to the cytoskeleton proteins - cytokeratin and tropomyosin, with a high frequency of occurrence to centromeric chromosome proteins ); and with the formation of mechanisms of peripheral selftolerance loss: maximum its increase in comparison with other groups of CD20+ expression; activation and increased expression of adhesion molecules $\mathrm{CD} 14+\mathrm{CD} 11 \mathrm{c}+$ and clusters of late activation on monocytes CD14+HLA-DR+.

In ontogeny, the nature of the disease progression in young patients with thymus-independent myasthenia gravis $(\mathrm{M})$ is determined by the mechanisms of the autoimmune process formation to the development of central or peripheral self-tolerance loss.

The revealed markers, which are specific for elderly patients with thymoma - the presence of HLA DR2 and HLA DR7 haplotypes, can serve as a basis for predicting the formation of structural and functional disorders of the thymus in the form of an autoimmunization focus in young patients; the presence of a target for autoantibodies in the thymus the $\alpha 7$-subunit of nicotinic acetylcholine receptors (nAChR) on thymocyte mitochondria, a high concentration of ANA and their certain specificities; a significant increase of the CD20+ expression of antibody-producing cells; increased expression of the adhesion molecules $(\mathrm{CD} 14+\mathrm{CD} 11 \mathrm{c}+)$ and a marker of late activation (CD14+HLA-DR+) of monocytes.

Thymectomy in some young patients with thymus-independent myasthenia gravis (M), in whom immune markers characteristic of thymoma patients were identified at the disease onset can be highly effective.

In the absence of these markers associated with thymoma, in the presence of only peripheral mechanisms of self-tolerance loss in $M$, it is inexpedient to deprive young patients of an important immunocompetent organ. 
Funding

The work was carried out in accordance with the research plan of V.T.Zaycev Institute of General and Urgent Surgery of National academy of medical sciences of Ukraine». The authors did not receive any financial support from companies manufacturing drugs and medical devices

\section{Conflict of interest}

The authors declare that they have no conflict of interest.

\section{Ethical aspects Ethics Committee approval}

The study was approved by Ethics Committee of V.T. Zaycev Institute of General and Urgent Surgery of National academy of medical sciences of Ukraine.

\section{ЛИТЕРАТУРА}

1. Carr AS, Cardwell CR, McCarron PO, McConville J. A systematic review of population based epidemiological studies in Myasthenia Gravis. BMC Neurol. 2010 Jun 18;10:46. doi: 10.1186/1471-2377-10-46

2. Phillips WD, Vincent A. Pathogenesis of myasthenia gravis: update on disease types, models, and mechanisms. F1000Res. 2016 Jun 27;5:F1000 Faculty Rev-1513. doi: 10.12688/f1000research.8206.1. eCollection

3. Klimova EM, Minuchin DV, Drozdova LA, Lavinskaya EV, Kordon TI, Kalashnykova YV. Features of self-tolerance loss in patients with different clinical phenotypes of myasthenia. Regul Mech Biosyst. 2018;9(4):561-67. doi: 10.15421/021884

4. Farmakidis C, Pasnoor M, Dimachkie MM, Barohn RJ. Treatment of Myasthenia Gravis. Neurol Clin. 2018 May;36(2):311-37. doi: 10.1016/j.ncl.2018.01.011 5. Schreuder GM, Hurley CK, Marsh SG, Lau M, Fernandez-Vina M, Noreen HJ, Setterholm M, Maiers M. The HLA Dictionary 2004: a summary of HLA-A, -B, -C, -DRB1/3/4/5 and -DQB1 alleles and their association with serologically defined HLA-A, -B, $-\mathrm{C},-\mathrm{DR}$ and -DQ antigens. Int J Immunogenet. 2005 Feb;32(1):19-69. doi: 10.1111/j.1744-313X.2005.00497.x 6. Gergalova GL, Lehmus OJ, SkokMV. Possible effect of activation of 7-nicotinic acetylcholine receptors in the mitochondrial membrane on the development of apoptosis. Neurophysiology. 2011;43(3):195-197. doi:10.1007/s11062-011-9203-7

7. Luider J, Cyfra M, Johnson P, Auer I. Impact of the new Beckman Coulter Cytomics FC 500 5-color flow cytometer on a regional flow cytometry clinical laboratory service. Lab Hematol. 2004;10(2):102-8. doi: 10.1532/LH96.04121

8. Klimova EM, Lavinskaya EV, Minukhin DV, Syrovaya AO, Drozdova LA, Samoilova AP, Makarov VV, Makarov VA, Lukiyanova LV. On forming central and peripheral markers of self-tolerance loss in diverse clinical myasthenic phenotypes. Der Pharmacia Lettre. 2017;9(6):8-17. http://scholarsresearchlibrary. com/archive.html

9. Hurst R, Rollema H, Bertrand D. Nicotinic acetylcholine receptors: from basic science to therapeutics. Pharmacol Ther. 2013 Jan;137(1):22-54. doi: 10.1016/j.pharmthera.2012.08.012

10. Yi JS, Guptill JT, Stathopoulos P, Nowak RJ, O'Connor KC. B cells in the pathophysiology of myasthenia gravis. Muscle Nerve. 2018 Feb;57(2):17284. doi: $10.1002 /$ mus. 25973

11. Drutman SB, Kendall JC, Trombetta ES. Inflammatory spleen monocytes can upregulate CD11c expression without converting into dendritic cells. $J$ Immunol. 2012 Apr 15;188(8):3603-10. doi: 10.4049/ jimmunol.1102741

\section{REFERENCES}

1. Carr AS, Cardwell CR, McCarron PO, McConville J. A systematic review of population based epidemiological studies in Myasthenia Gravis. BMC Neurol. 2010 Jun 18;10:46. doi: 10.1186/1471-2377-10-46

2. Phillips WD, Vincent A. Pathogenesis of myasthenia gravis: update on disease types, models, and mechanisms. F1000Res. 2016 Jun 27;5:F1000 Faculty Rev-1513. doi: 10.12688/f1000research.8206.1. eCollection

3. Klimova EM, Minuchin DV, Drozdova LA, Lavinskaya EV, Kordon TI, Kalashnykova YV. Features of self-tolerance loss in patients with different clinical phenotypes of myasthenia. Regul Mech Biosyst. 2018;9(4):561-67. doi: 10.15421/021884

4. Farmakidis C, Pasnoor M, Dimachkie MM, Barohn RJ. Treatment of Myasthenia Gravis. Neurol Clin. 2018 May;36(2):311-37. doi: 10.1016/j.ncl.2018.01.011 5. Schreuder GM, Hurley CK, Marsh SG, Lau M, Fernandez-Vina M, Noreen HJ, Setterholm M, Maiers M. The HLA Dictionary 2004: a summary of HLA-A, -B, -C, -DRB1/3/4/5 and -DQB1 alleles and their association with serologically defined HLA-A, -B, $-\mathrm{C}$, -DR and -DQ antigens. Int J Immunogenet. 2005 Feb;32(1):19-69. doi: 10.1111/j.1744-313X.2005.00497.x 6. Gergalova GL, Lehmus OJ, SkokMV. Possible effect of activation of 7-nicotinic acetylcholine receptors in the mitochondrial membrane on the development of apoptosis. Neurophysiology. 2011;43(3):195-197. doi:10.1007/s11062-011-9203-7

7. Luider J, Cyfra M, Johnson P, Auer I. Impact of the new Beckman Coulter Cytomics FC 500 5-color flow cytometer on a regional flow cytometry clinical laboratory service. Lab Hematol. 2004;10(2):102-8. doi: 10.1532/LH96.04121

8. Klimova EM, Lavinskaya EV, Minukhin DV, Syrovaya AO, Drozdova LA, Samoilova AP, Makarov VV, Makarov VA, Lukiyanova LV. On forming central and peripheral markers of self-tolerance loss in diverse clinical myasthenic phenotypes. Der Pharmacia Lettre. 2017;9(6):8-17. http://scholarsresearchlibrary. com/archive.html

9. Hurst R, Rollema H, Bertrand D. Nicotinic acetylcholine receptors: from basic science to therapeutics. Pharmacol Ther. 2013 Jan;137(1):22-54. doi: 10.1016/j.pharmthera.2012.08.012

10. Yi JS, Guptill JT, Stathopoulos P, Nowak RJ, O'Connor KC. B cells in the pathophysiology of myasthenia gravis. Muscle Nerve. 2018 Feb;57(2):17284. doi: $10.1002 /$ mus. 25973

11. Drutman SB, Kendall JC, Trombetta ES. Inflammatory spleen monocytes can upregulate CD11c expression without converting into dendritic cells. $J$ Immunol. 2012 Apr 15;188(8):3603-10. doi: 10.4049/ jimmunol.1102741 
Адрес для корреспонденции

61103, Украина,

г. Харьков, въезд Балакирева, 1,

Институт общей и неотложной хирургии

им. В.Т. Зайцева НАМН Украины,

диагностическая лаборатория,

тел.: +380 503033172 ,

e-mail: klimovalena53@gmail.com,

Климова Елена Михайловна

\section{Сведения об авторах}

Климова Елена Михайловна, д.б.н., профессор, заведующая диагностической лабораторией с иммуноферментным и иммунофлуоресцентным анализом, Институт общей и неотложной хирургии им. В.Т. Зайцева НАМН Украины, г. Харьков, Украина.

https://orcid.org/0000-0002-4007-6806

Бойко Валерий Владимирович, член-корреспондент Национальной Академии медицинских наук Украины, д.м.н., профессор, директор, Институт общей и неотложной хирургии им. В.Т. Зайцева НАМН Украины, г. Харьков, Украина.

https://orcid.org/0000-0003-4771-9699

Дроздова Лариса Анатольевна, к.б.н., старший научный сотрудник диагностической лабораторией с иммуноферментным и иммунофлуоресцентным анализом, Институт общей и неотложной хирургии им. В.Т. Зайцева НАМН Украины, г. Харьков, Украина.

https://orcid.org/0000-0001-9678-4046

Лавинская Елена Владимировна, к.б.н., научный сотрудник диагностической лаборатории с иммуноферментным и иммунофлуоресцентным анализом, Институт общей и неотложной хирургии им. В.Т. Зайцева НАМН Украины», г. Харьков, Украина.

https://orcid.org/0000-0001-7320-0925

Минухин Дмитрий Валерьевич, к.м.н., доцент кафедры хирургии № 1 Харьковского национального медицинского университета, г. Харьков, Украина. https://orcid.org/0000-0003-3371-1178

Кудревич Александр Николаевич, к.м.н., заведуюший кафедрой хирургических болезней, оперативной хирургии и топографической анатомии, Харьковский национальный университет им. В.Н. Каразина, г. Харьков, Украина.

https://orcid.org/0000-0002-2086-8822

\section{Информация о статье}

Поступила 8 мая 2020 г.

Принята в печать 5 июля 2021 г.

Доступна на сайте 1 сентября 2021 г.

\section{Address for correspondence}

61103, Ukraine,

Kharkov, Balakireva vyizd, 1,

V.T. Zaycev Institute of General and Urgent Surgery

of National Academy of Medical Sciences of Ukraine,

Diagnostic Laboratory,

Tel. +38(057)3494115,

E-mail: klimovalena53@gmail.com,

Klimova Olena M.

\section{Information about the authors}

Klimova Olena MD (Biol.), Professor, Head of the Diagnostic Laboratory with Enzyme Immunoassay and Immunofluorescence Analysis, V.T. Zaycev Institute of General and Urgent Surgery of NAMS of Ukraine, Kharkov, Ukraine.

https://orcid.org/0000-0002-4007-6806

Boyko Valery V., Corresponding Member of National Academy of Medical Sciences of Ukraine, MD, Professor, Director of V.T. Zaycev Institute of General and Urgent Surgery of National Academy of Medical Sciences of Ukraine, Kharkov, Ukraine. https://orcid. org/0000-0003-4771-9699

Drozdova Larisa A., Candidate of Biological Sciences, Senior Researcher, the Diagnostic Laboratory with Enzyme Immunoassay and Immunofluorescence Analysis, V.T. Zaycev Institute of General and Urgent Surgery of NAMS of Ukraine, Kharkov, Ukraine. https://orcid.org/0000-0001-9678-4046

Lavinska Olena V., PhD(Biol.), Researcher, the Diagnostic Laboratory with Enzyme Immunoassay and Immunofluorescence Analysis, V.T. Zaycev Institute of General and Urgent Surgery of NAMS of Ukraine, Kharkov, Ukraine.

https://orcid.org/0000-0001-5813-3656

Minukhin Dmitriy V., PhD, Associate Professor of The Surgery Department No1, V.N. Karazin Kharkiv National Medical University, Kharkov, Ukraine https:// orcid.org/0000-0003-3371-1178

Kudrevych Oleksandr M., PhD, Associate Professor, Head of the Department of Surgical Diseases, Operative Surgery and Topographical Anatomy, V.N. Karazin Kharkiv National Medical University, Kharkov, Ukraine https://orcid.org/0000-0002-2086-8822

\section{Article history}

Arrived: 8 May 2020

Accepted for publication: 5 July 2021

Available online: 1 September 2021 